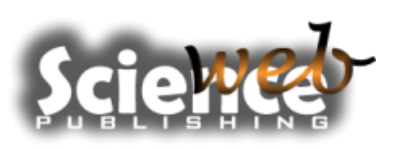

\title{
Rice and maize price competitiveness in Senegal: Market integration and price causation between Saint- Louis market and Mpal market
}

\author{
Arame Top* $\bullet$ Kwansoo Kim
}

Department of Agricultural and Rural Development, Seoul National University, Seoul, South Korea.

*Corresponding author. E-mail: arametoptofa@yahoo.fr.

Accepted $11^{\text {th }}$ January, 2019.

\begin{abstract}
The Granger-causality test results revealed that the causality direction is from urban area to rural area for the price of rice and from rural area to urban area for the price of maize. These results suggest that the amount of subsidy on rice imports needs to be redirected towards productivity and quality increase, to shift the consumption of rice from imported rice to domestically produced rice. For maize, policy attention should be given to the increase in productivity of domestic maize giving preference to Senegalese local maize. This effort would increase the supply of domestic maize with which the price of domestic maize in a rural market would decline. Given Granger-causality test results for maize; this would signal a downward pressure on the price of imported maize in an urban market where imported maize is mainly consumed in a livestock sector and agri-industry.
\end{abstract}

Keywords: Granger-causality test, market integration, Senegal River Valley.

Abbreviations: ANSD: National Agency of Statistics and Demography (Agence Nationale de la Statistique et de la Démographie); FCFA: Africa Financial Community Franc (West Africa currency); IRRI: International Rice Research Institute; MEF: Ministère de l'économie et des finances (Finance and Economy Ministry); OFS (CSA): Office of Food Security (Commissariat de la Sécurité Alimentaire); SRV: Senegal River Valley.

\section{INTRODUCTION}

Market volatility and prices soaring of international food, particularly for cereals, did not spare Senegal which imports 60 percent (ANSD, 2009) of its needed food. This overall situation is mainly due until June to July 2008 to an eventual rising speculation in oil prices which affected agricultural production sector, the strong demand in cereal for bio-fuels and the increasing demand in cereal for livestock in developed countries (mainly in USA and Europe for maize crop) as well as the increasing consumption in emerging countries (Brasilia, East part of Asia and climate changes. This situation had led exporters of rice to decrease, and see to stop their sales in order to replenish their stocks and stabilize their domestic prices (Niang and Ndiaye, 2010) because supply was limited, and producing countries needed to protect the sustainability of their markets.

In Senegal, the high level of basic imported food prices hampered their accessibility, mainly for the rice which is the basic Senegalese staple. In late 2007 and early 2008, importers faced harsh difficulties due to the high volatility of food prices in the international markets, shortage in supply and lack of available funds. Thus, to alleviate Senegalese daily charges, the government subsidized activities of rice importers in order to make prices more affordable to consumers.

Indeed, there is a weak correlation between the Free 

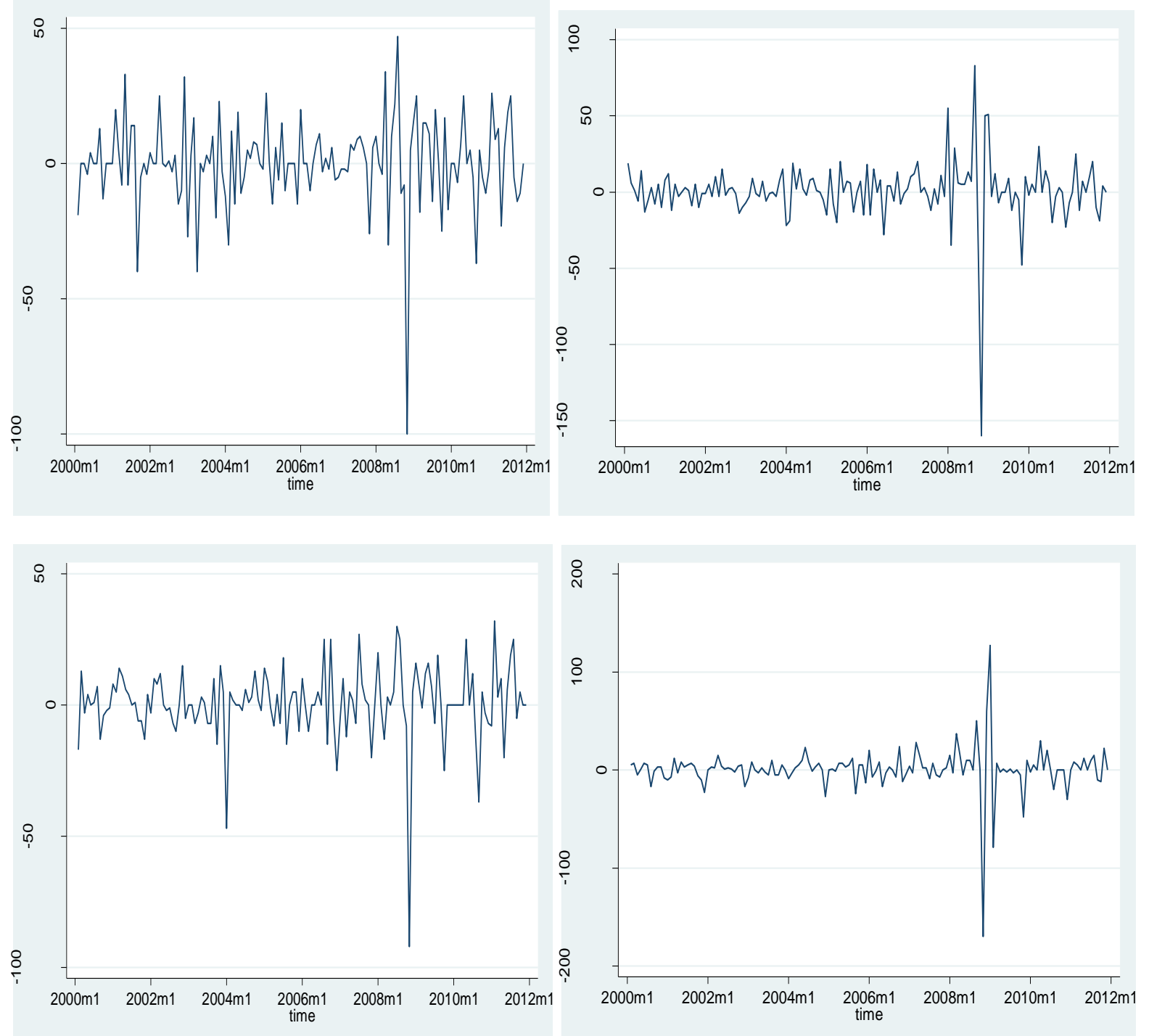

Figure 1. Differenced price.

On Board (FOB) price of rice and domestic price (i.e., import price + government subsidy + transportation costs) of rice (coefficient of correlation $=0.3189$ ) as well as between FOB price of maize and domestic price of maize (coefficient of correlation $=0.4436$ ). These results are due to subsidy policies on rice and Senegalese preference of local maize, respectively (Figures 2 and 3). In the area of Senegal River Valley, local prices of rice and maize are found to be highly correlated in SaintLouis market (Figure 3), which is located in an urban area (a coefficient of correlation $=0.7025$ ) and in Mpal market (Figure 5) as well, which is located in a rural area (coefficient of correlation $=0.6852$ ). This implies rice and maize are substitutes in Senegal.

Indeed this dependency of Senegal on imports can be explained by sustainable socio-economic factors since the colonial period. Cereal production was neglected during colonial and post-colonial period since it was not as profitable as cash crops (peanut and cotton). These commercial crops were characterized by high income resources compared to other crops (rice, millet, sorghum, maize etc.) with an efficient support from the government and some European countries as France, and a wellorganized commercialization in the entire sector (from input production to output marketing). And from these cash crops emergence till now, Senegalese's rice market is characterized by a persistent preference of broken imported rice despite of its low quality in the world market. Furthermore, the price of local rice is always lower than the imported one (Figure 6). This phenomenon is due to people's adaptation to the available rice during colonial and post-colonial period.

Therefore, in order to overcome foreign currency loss and economic recovery, food crop production is important 


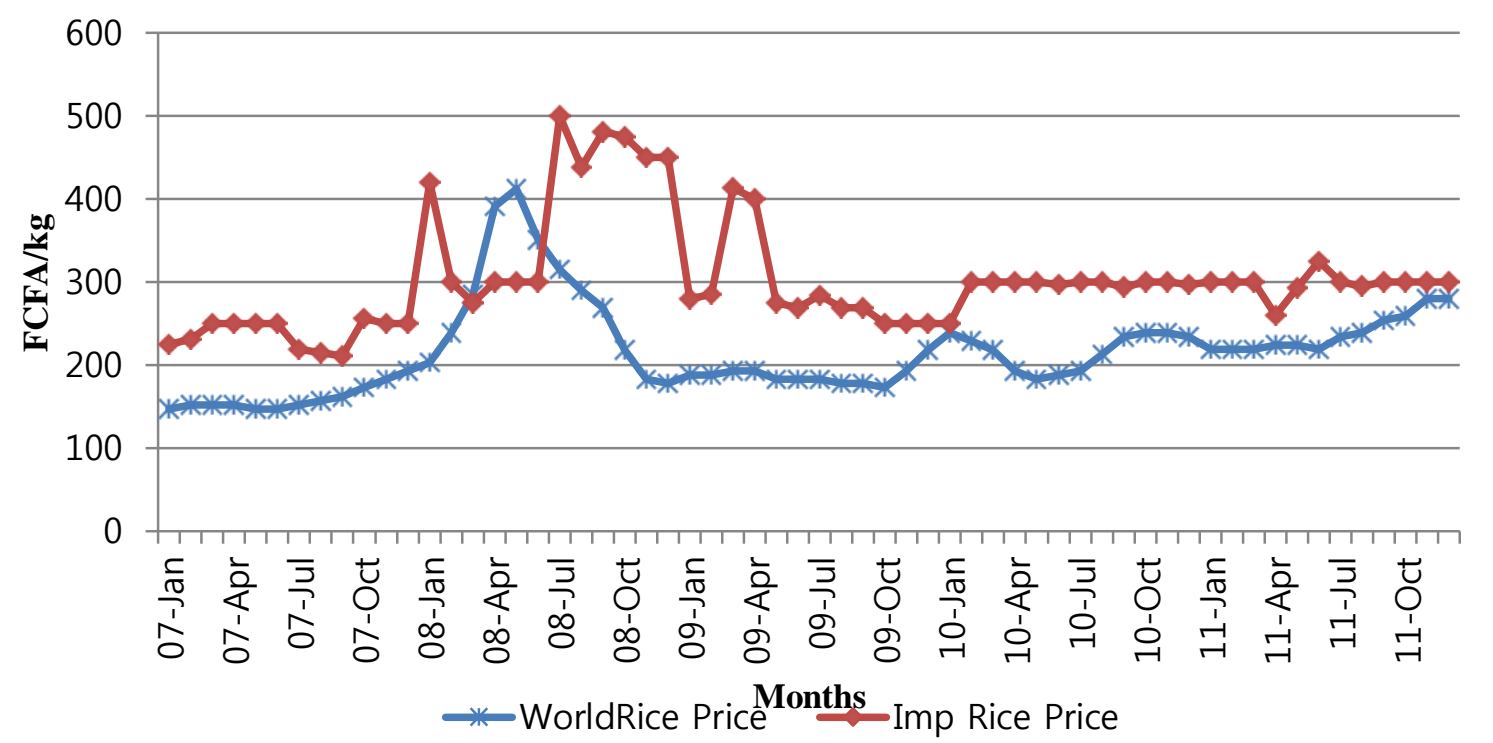

Figure 2. International (FOB) and consumer prices of rice in Dakar at Tilene market. Source: OFS (2012).

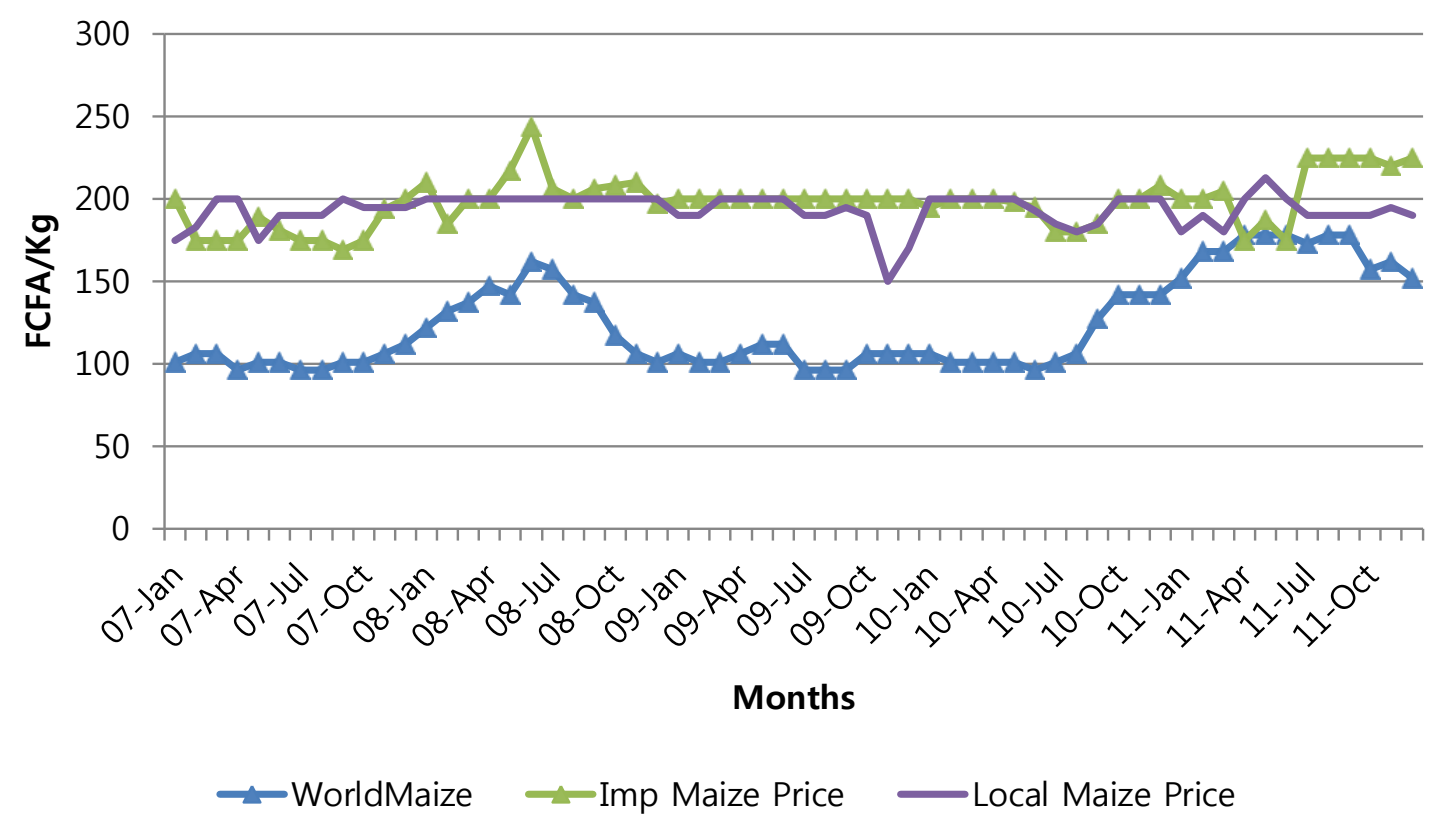

Figure 3. International (FOB) and consumer prices of maize in Dakar at Tilene market. Source: OFS (2012).

because foreign currency loss caused by imports is about $\$ 240$ million for the rice and \$20 million for the maize per year since 2006 (ANSD, 2011). Also, the government has lost $\$ 6$ million because of subsidies on rice imports and suspension of custom duties on imported rice trade. Then loss in foreign currency caused by 2008 crisis would have been lower if import dependency was less.

\section{LITERATURE REVIEW}

Most of Senegalese government interventions in the rice market in order to control and regulate subsidized prices were negative. They caused the insistence of prices soaring and stable scarcity (retention and intractability) for the rice (MEF, 2008; Niang and Ndiaye, 2010). However, government interventions were positive in the maize sector because maize market is characterized by local varieties prices which are higher than imported maize prices due to its preference by Senegalese. And the emergence of product/sell contracts boosted the maize sector by making it more organized and attractive (Andrew, 2011). Then, as for rice, the preference is given to the imported rice, and the cropping of tasty and quick 


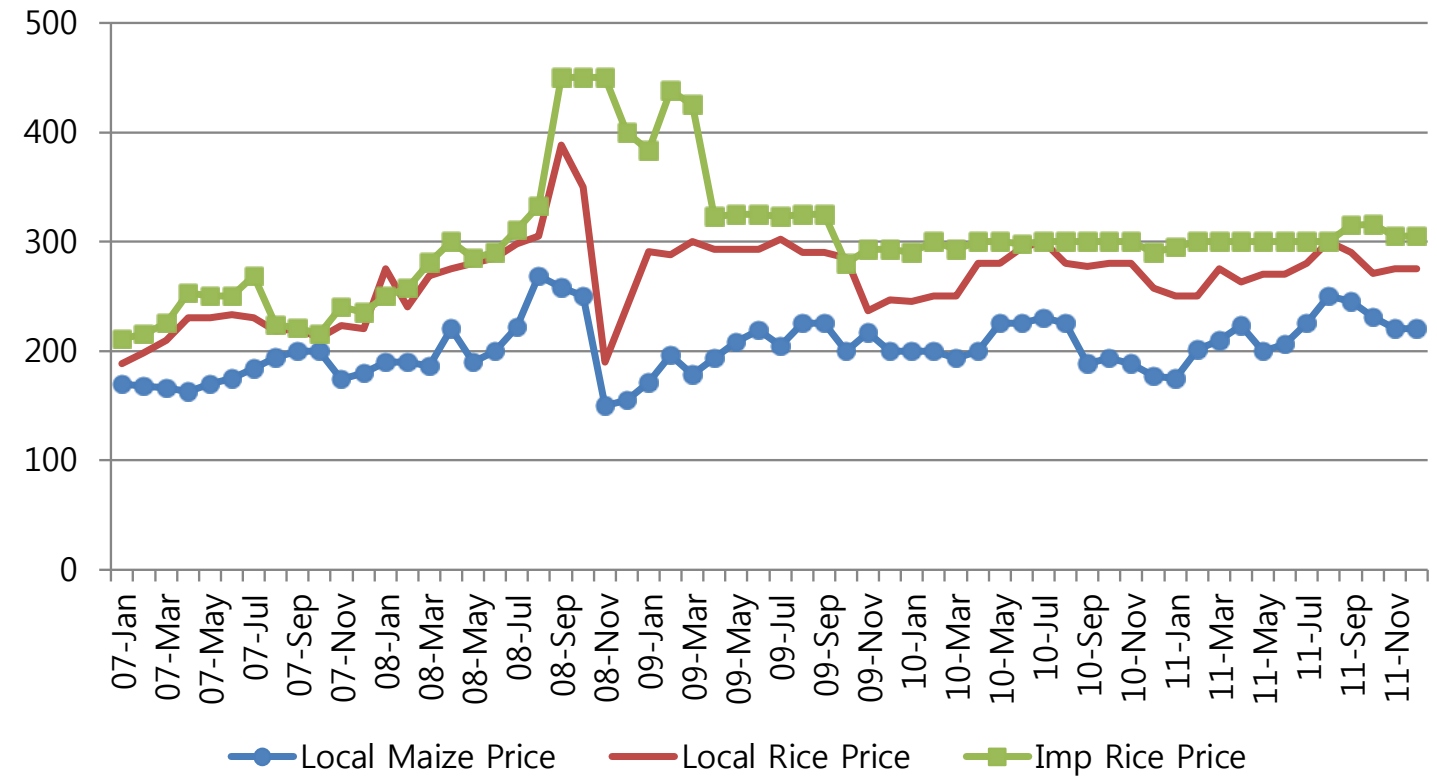

Figure 4. Local husked rice, local maize and imported broken rice consumer prices in Saint-Louis market. Source: OFS (2012).

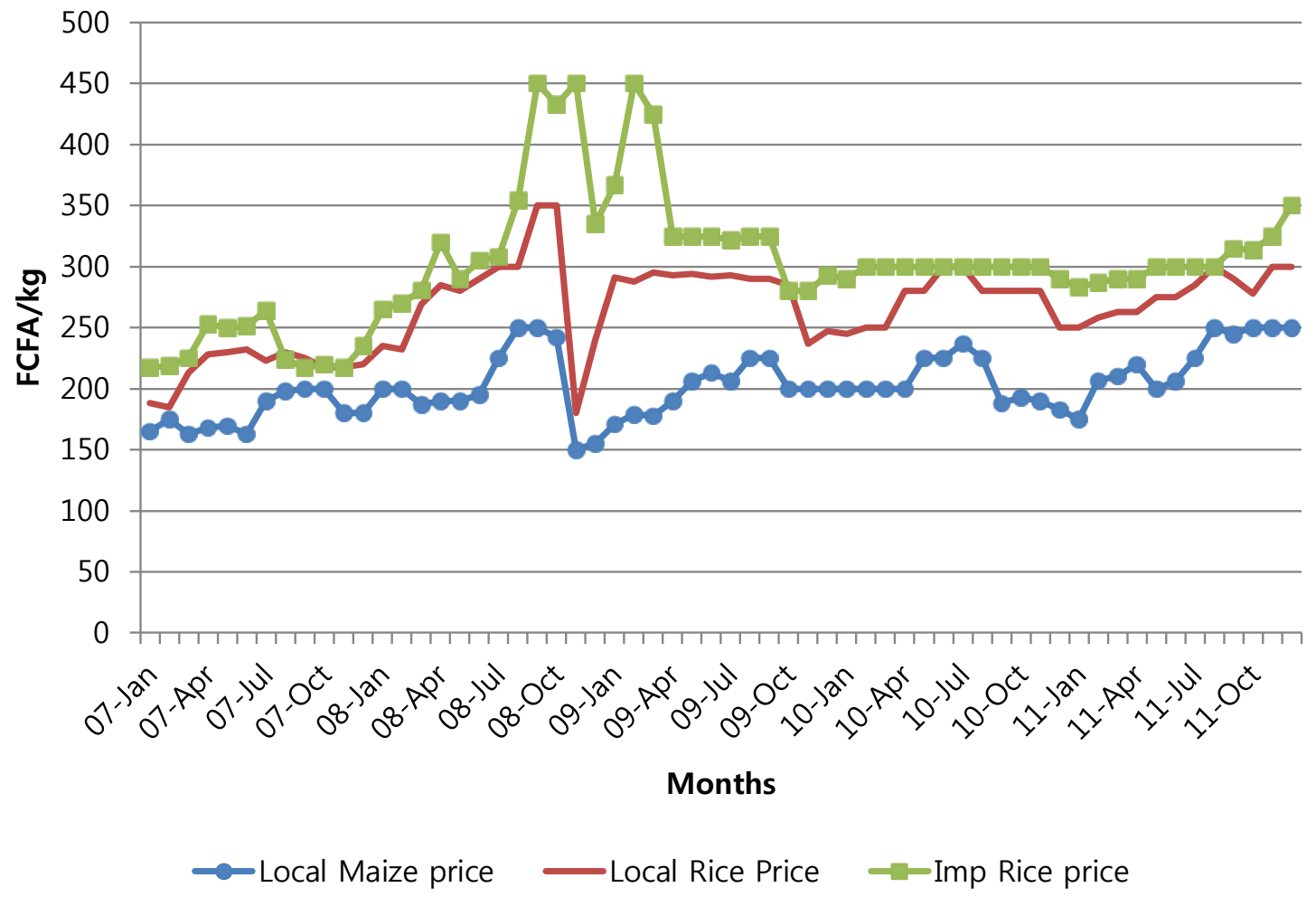

Figure 5. Local maize, local husked rice and imported broken rice consumer prices in the market of Mpal. Source: OFS (2012).

to cook rice will increase the domestic demand of rice (IRRI, 2011). Indeed with 60 and $49 \%$ of food budget share on revenue, rice consumption represents 16 and $11 \%$ of Senegalese spending respectively in rural and urban area with an increasing perspective (World food program, 2008). For these challenges, Senegalese agricultural agents rely on how to produce sufficient and affordable rice that meet the preferences of its fast growing and 


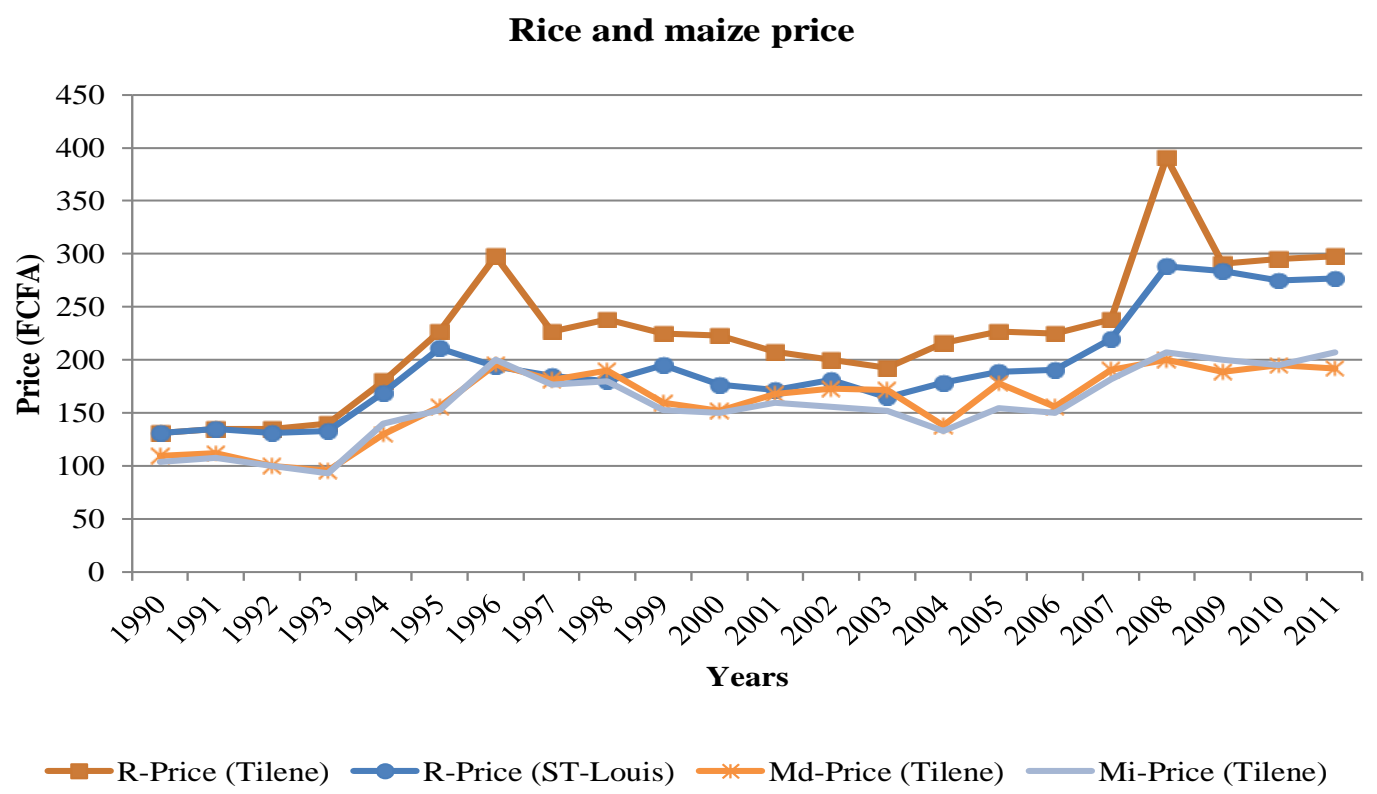

Figure 6. Rice and maize price trends. Source: FSO (2012).

Table 1. Descriptive statistics of variables from January 2000 to December 2011.

\begin{tabular}{llccccc}
\hline Variables & Descriptions & Obs & Mean & Std. Dev & Min & Max \\
\hline SLImp & Saint-Louis local maize price & 144 & 181.42 & 28.31 & 125 & 269 \\
SLIrp & Saint-Louis local rice price & 144 & 218.79 & 47.11 & 149 & 388 \\
Mlmp & Mpal local maize price & 144 & 175.1 & 31.79 & 250 & 250 \\
Mlrp & Mpal local rice price & 144 & 210.19 & 55.33 & 140 & 367 \\
\hline
\end{tabular}

Source: FSO (2012).

increasing urbanized population (Niang and Ndiaye, 2010; IRRI, 2011). In this context, and according to the huge comparative advantage of Senegal in cereal production, mainly for rice and maize (Africa Rice, 2009), and the complexity of market redressing, particularly in the rice sector, priorities should be on a selective subsidy system, an import rationalization to avoid re-import in other neighboring countries, a creation of a dynamic consulting and dialogue framework between agricultural experts and stakeholders, and an enhancing domestic agricultural production to reduce progressively and sustainably the country dependence on imports. Many agricultural policies have been developed to upgrade sustainably the agricultural production of Senegal vainly. Therefore, the purpose of this research is to find how to boost production by testing market integration between rural and urban areas.

\section{METHODOLOGY}

The conceptual model of analysis is build based on the analysis of national markets and prices policies in Coxhead et al. (2001). The analysis focuses on prices effects of market integration on policy making for sustainable agricultural production and self-sufficiency achievement.

\section{Data}

The used data is a monthly time series data of local and imported price of rice and maize in Senegal River valley from January 2000 to December 2011. (Table 1) The analysis focuses mainly on Saint-Louis urban market and Mpal rural market in the Senegal River Valley. The main source of data is from the Food Security Office. However, some adjustments have been done one data after literature review to make it suitable to an empirical analysis.

\section{RESULTS AND DISCUSSION}

\section{Empirical analysis: Market integration and price causation}

This market analysis will rely on Saint-Louis and Mpal 
markets where price data is more available and reliable. The empirical analysis will rely on the integration of these two markets (urban and rural) through the GrangerCausality test in order to determine the direction of price causation.

Market integration and price causation direction of agricultural products are very important in policy makers' decisions. Normally if they are well defined, conducted policies would absolutely lead to a sustainable agricultural production as well as to the improvement of the environment. Then, there will be an improvement of the socio-economic conditions, situation of farmers' which depends also on the management of their own agricultural revenues.

As agricultural sector is now liberalized, farmers should be aware about the notion of competitiveness and try to take off their activities efficiently, and since the government cannot continuously subsidize agricultural inputs, farmers and mainly family farming producers must have a notion of saving and not to expect always everything from the government or try to move into cities expecting better life without any qualification. The reorganization of farmers is necessary and imperative because they usually make the management of cities difficult to undertake, mainly in Dakar cities which are the main poles of convergence of rural people.

Then, as Saint-Louis market and Mpal market are highly correlated, price causation direction is a prominent element in the implementation of priorities. It will help in the improvement of the domestic production as well as in the fixation of policies.

The vector autoregressive model is as follow:

$$
\begin{aligned}
& P U_{A t}=\alpha_{1} P R_{B t}+\beta_{11} P U_{A t-1}+\beta_{12} P U_{A t-2}+\ldots \ldots \ldots \ldots .+\beta_{1 n} P U_{A t-} \\
& n+V_{P u t} \\
& P R_{B t}=\alpha_{2} P U_{A t}+\beta_{21} P R_{B t-1}+\beta_{22} P R_{B t-2}+\ldots \ldots \ldots \ldots \ldots+\beta_{2 n} P R_{B t-} \\
& n+V_{P B t}
\end{aligned}
$$

Or

$P U_{A t}=\alpha_{1} P R_{B t}+\beta_{1 p} P U_{A t-p}+V_{P u t}$

$P R_{B t}=\alpha_{2} P U_{A t}+\beta_{2 p} P U_{A t-p}+V_{P R t}$

Where:

PU and PR are urban and rural market prices in Senegal River Valley,

A: represents Saint-Louis market,

$\mathrm{B}$ : represents Mpal market,

t: represents period, monthly price from January 2000 to December 2011,

$V_{\text {PUt }}$ and $V_{\text {PRt }}$ are error terms which are assumed to be uncorrelated,

$\alpha$ and $\beta$ are some parameters,

$p$ : is an integer, $p=1,2,3, \ldots, N$,

$n$ : is an integer, $n=3,4,5, \ldots, N$.
Equations 1 and 2 have endogenous variables in their right hand side. Then, the VAR model is under a structural form. The structural form must be reduced. The transformation of the structural equation will lead to:

$\mathrm{PU}_{\mathrm{At}}=\Phi_{11} \mathrm{PU}_{\mathrm{At}-1}+\Phi_{12} \mathrm{PU}_{\mathrm{At}-2}+\Phi_{1 \mathrm{n}} \mathrm{PU} U_{\mathrm{At}-\mathrm{n}}+\Phi_{21} \mathrm{PR}_{\mathrm{Bt}-1+}$ $\Phi_{22} \mathrm{PR}_{\mathrm{Bt}-2}+\quad \Phi_{2 \mathrm{n}} \mathrm{PR}_{\mathrm{Bt}-\mathrm{n}}+\varepsilon_{1 \mathrm{t}}$ (3)

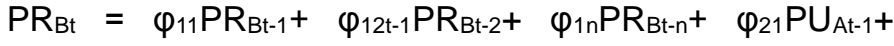
$\varphi_{21} \mathrm{PU}_{\mathrm{At}-2}+\varphi_{2 \mathrm{n}} \mathrm{PU}_{\mathrm{At}-\mathrm{n}}+\varepsilon_{2 \mathrm{t}}$

Where:

$\Phi$ and $\varphi$ are some parameters,

$\varepsilon_{1 \mathrm{t}}$ and $\varepsilon_{2 \mathrm{t}}$ are unobservable error term variables which are serially uncorrelated.

To estimate the VAR model properly, there is a need of data stationary. The above trends of prices in Saint-Louis and Mpal markets show that prices are not stationary. Furthermore, the unit root test by Dickey Fuller test confirms that data is a non-stationary (Figure 1) time series data. Then the time series should be differentiated to make it stationary. After the first differencing, the Phillips Peron test shows that data is now stationary as represented in the Figure 1.

From here, the VAR model lag-length can be estimated to determine the number of lags. The optimal lag length estimated is two. Thus, the equation (3) can be rewritten with a lag length of two-period as follow:

$\mathrm{PU}_{\mathrm{At}}=\Phi_{11} \mathrm{PU}_{\mathrm{At}-1}+\Phi_{12} \mathrm{PU}_{\mathrm{At}-2}+\Phi_{21} \mathrm{PR}_{\mathrm{Bt}-1}+\Phi_{22} \mathrm{PR}_{\mathrm{Bt}-2}+\varepsilon_{1 \mathrm{t}}$ (4)

$\mathrm{PR}_{\mathrm{Bt}}=\varphi_{11} \mathrm{PR}_{\mathrm{Bt}-1}+\varphi_{12} \mathrm{PR}_{\mathrm{Bt}-2}+\varphi_{21} \mathrm{PU}_{\mathrm{At}-1}+\varphi_{22} \mathrm{PU}_{\mathrm{At}-2}+\varepsilon_{2 \mathrm{t}}$

The Granger causality test will be done with differentiated variables of the data, first differences. And the null hypothesis is:

$\mathrm{H}_{01}: \Phi_{21}=\Phi_{22}=0$ : Mpal market price fails to Grangercause Saint-Louis market price,

$\mathrm{H}_{02}: \varphi_{21}=\varphi_{22}=0$ : Saint-Louis market price fails to Granger-cause Mpal market price.

Granger causality tests utilize test statistics computed from the VARs. A variable $X_{t}$ is said to fail, to Grangercause another variable $Y_{t}$, relative to an information set consisting of past values of $X_{t}$ and $Y_{t}$, if:

$\hat{E}\left[Y_{t} \mid Y_{t-1}, X_{t-1}, Y_{t-2}, \ldots\right]=\hat{E}\left[\begin{array}{lllll}Y_{t} & Y_{t-1}, & Y_{t-2}, & \ldots\end{array}\right]$ (5)

Where $\hat{E}$ denotes a linear projection of the dependent variable. In this case, this means that Saint-Louis market price does not Granger-cause Mpal market price relative to an information set consisting of past values of SaintLouis and Mpal markets if and only if the estimates of $\varphi_{21}$ 
Table 2. Granger-Causality tests of local maize and local husked rice prices.

\begin{tabular}{llccl}
\hline Crops & Causality test & $\mathbf{R}^{\mathbf{2}}$ & Prob $>\mathbf{c h i}^{\mathbf{2}}$ & Comments \\
\hline \multirow{2}{*}{ Rice } & Saint-Louis $\rightarrow$ Mpal & 0.8461 & 0.009 & \multirow{2}{*}{ One-way causation } \\
& Mpal $\rightarrow$ Saint-Louis & 0.8351 & 0.364 & \\
& & & & \\
\multirow{2}{*}{ Maize } & Saint-Louis $\rightarrow$ Mpal & 0.8141 & 0.667 & \multirow{2}{*}{ One-way causation } \\
& Mpal $\rightarrow$ Saint-louis & 0.7343 & 0.000 & \\
\hline
\end{tabular}

and $\varphi_{22}$ are equal to zero. The results of these Granger causality tests are summarized in Table 2.

The Granger causality test shows that markets are integrated between them for rice and maize crops in oneway causation. For the rice, Mpal market price Grangercauses Saint-Louis market price, thus, the hypothesis is rejected and the opposite sense of causality direction is accepted. In maize market, Mpal market price Grangercauses Saint-Louis market. However, Saint-Louis market price does not Granger-cause the price of Mpal market in one-way.

For the husked rice, the causality direction between Saint-Louis market and Mpal market is from Saint-Louis market to Mpal market. It means that rural price is highly driven by the urban market price at one percent level of significance. Then, the increase of urban price will also lead to the increase of rural price in rice sector. But for the maize, the direction of causality is from Mpal market to Saint-Louis market. So if subsidy on imported rice is limited or stopped, urban price of rice will obviously increase and that will encourage farmers to produce more to satisfy domestic demand as well as to improve their incomes. Furthermore, as imported and husked local rice are highly correlated in Saint-Louis market (0.6027), the imported one will be substituted by the domestic rice. Then, the demand of the local husked rice will increase considerably as well as its price. This increasing price of rice in Saint-Louis market will at its turn drive up Mpal's price and motivate farmers more in rice production. As Senegal is highly dependent on imports from mainly Asian countries, the improvement of rice production as well as its sustainability can be a huge source of revenue for rural people (farmers and traders). Moreover, it will lead to family farming resurrection and can solve the rural exodus matter. If subsidy amount is oriented in agricultural infrastructure building, production can be boosted sustainably while creating job for young people in rural areas and moderating rural exodus.

Then, with an efficient improvement of rice production, farmers' revenues will be improved obviously and the volume of imported rice can be reduced significantly. In addition, if this dynamism is sustained in the country for a long period, self-sufficiency in rice may be achieved in short term.

In maize sector, the Granger-causality direction is from Mpal market to Saint-Louis market contrary to Coxhead and Al (2001); result where farm gate prices are driven by provincial prices. Then rural maize price drives entirely the urban one at one percent significance level. However, since the price of rice in Saint-Louis market strongly affects the one of Mpal market, the government should revise and reduced the amount of subsidy on rice import to highly motivate rice and maize production. The amount of subsidy must be oriented towards production infrastructure building to sustain the production of rice and maize in SRV. Then, if production competitiveness of local rice is harmonized by a scale of production, it will improve the security of supply and considerably reduce Senegal's import dependency.

As preference is given to local varieties for maize, efforts should be on efficient production to compete sustainably with the imported maize. Indeed, according to the socio-economic conditions, if local maize price increases considerably, people will substitute it to the imported one if its price becomes more affordable than the price of domestic maize. Furthermore, agri-industry must be improved for maize processing in order to adapt its sub-products to the increasing needs of urban areas. This appropriation can lead to the decrease in rice demand as rice is one of the popular cereals easier to use in Senegal with less preparation and less cooking time. Furthermore, in the maize sector, as imported and local maize prices are now nearly close to each other because of the increasing demand of maize (poultry and agri-industry emergence), priorities should be on the scale of production for farmers to produce at less cost in order to compete sustainably with imported maize.

\section{CONCLUSION AND RECOMMENDATIONS}

The weakness of domestic production of cereals and the quasi dependency of the country on imports, $77.9 \%$ (2011) and $35.7 \%$ (2010) for rice and maize respectively, do not show a best image of Senegal's agricultural sector. Thus, efficient and sustainable rice and maize production are and will remain for long time a crucial business opportunities, niche of employment as well as wealth creation mainly in areas suitable to double crop.

However silos structures for the support of agricultural production, the lack of strategy in the elaboration of programs, the different types of interventions implemented and applied, which are added some time by the groping vision status of the government to support 
agricultural institutions in order to reduce the country dependency on imports do not allow the achievement of expected results and agriculture development. Indeed, even though some industries promoted the consumption of local cereals through the transformation of agricultural products and adapt them to Senegalese's current needs, there is a particular and permanent need of promotional support to increase their market share.

It is unrealistic to expect to reverse of the dominant trend of rice consumption in Senegalese diet if it remains that rice and maize production improvement can validly regulate the system significantly and reduce Senegal dependency on imports. Self-sufficiency in rice can be realized if previous malfunctions are considered, and if challenges for food security and sovereignty are really well defined based on efficient development of policies and programs. A strong political willingness, sustained by local products consumption, marketing boosting and strategic complicities between partners are the key factors to achieve expected changes particularly in maize and rice sectors and Senegalese agriculture in general.

Farmers are generally price takers for rice, and as imported and local husked rice are highly correlated these last years due to the soaring prices of imported rice, the government should invest more efficiently in the agricultural sector for sustainable macroeconomic stability rather than on import subsidy. In maize sector, realized efforts should be maintained and improved to avoid the increase of its dependency, and to expect a future self-sufficiency in maize.

The Granger-causality test between Saint-Louis market and Mpal market shows that price causality direction is unique (one-way causation) in rice and maize marketing. Then, in Senegal River Valley for rice, Mpal market prices are highly influenced by the Saint-Louis market ones, and efforts concentrated in rice import and imported rice subsidy must be oriented towards boosting rice production. If there was no subsidy policy, imported rice price would be higher than applied prices under the combined international effects of increasing price of rice as well as the one of the black gold (barrel price). It is therefore necessary to include all import costs in prices as incentive for local production. However, this system presupposes that, main factors of pre-production, production and post production infrastructures and equipment are already available. Then instead of trying to decrease imported price of rice, priorities should be focused on boosting production, and produced rice varieties must also meet consumers' requirements and desires, above all the quality, quantity and calibration.

In the maize sector, the Granger-causality sense is from rural area (Mpal) to urban area (Saint-Louis). Then contrary to the rice sector, the rural market prices drive entirely the one of Saint-Louis market at one percent level of significance. This is due to the fact that local maize is preferred than the imported one. Furthermore, most of the imported maize is mainly for agri-industries and livestock. Therefore, the necessary efforts to improve maize production seem to be lower than that of the rice as its demand is already important, as well as its price level. For this reasons, public and private investors have to seize this market opportunity to satisfy all maize demand. The improvement of maize processing should be added to priorities to ease rice substitution by maize. Indeed, with a high urbanization rate $(46.8 \%)$ as well as an increasing number of active women, cooking time should be adjusted to women activities. Then, for the improvement of rice and maize sectors, these two sectors must have standard storage, calibration and packaging to attract an ever increasing number of regular customers.

\section{REFERENCES}

Africa Rice (2009). "Fast-tracking farmers' access to research innovation".

Andrew K (2011). "The Senegal Local Support Fund: Capacity building for maize value chain", July 20.

Agence Nationale de la Statistique et de la Démographie, ANSD (2009). Situation économique du pays.

Agence Nationale de la Statistique et de la Démographie, ANSD (2011). Situation économique du pays.

Coxhead I, Agnes R, Kwansoo K (2001). "How Do National Markets and Price Policies Affect Land Use at the Forest Margin? Evidence from the Philippines", Land Economics May 1, 77(2):250-267.

International Rice Research Institute/Rice Today (2011). JanuaryMarch.

Ministère de l'économie et des finances (MEF), (2008). "Rapport national sur le développement durable" Mai.

Niang M, Ndiaye M (2010). "De l'étude sur la transmission des fluctuations et le calcul des prix de parité à l'importation/exportation dans la sous-région : Cas pratique du Sénégal", janvier 2010.

World Food Program (2008). "Senegal: Rice trade" August 2008. 